\title{
Performance and Evaluation of Drip Irrigation System, and Its Future Advantages
}

\author{
Ameer Hussain Jarwar ${ }^{\mathbf{1}, 3} \quad$ Xiaoyan Wang ${ }^{\mathbf{2}} \quad$ Long Wang $^{\mathbf{1}} \quad$ Naimatullah Mangi $^{1} \quad$ Qifeng Ma*1 $^{2}$ \\ Fan Shuli*1 \\ 1 State Key Laboratory of Cotton Biology, Institute of Cotton Research of CAAS, Anyang 455000, China \\ 2 Anyang Institute of Technology, College of Biology and Food Engineering, Anyang, 455000, China \\ 3 Oil Seeds Section, Agriculture Research Institute, Tandojam, Sindh, Pakistan
}

\begin{abstract}
The drip irrigation system is a kind of micro-irrigation system that has the potential to salvage the water and other nutrients by entrance water to drip gradually to the main roots of plants and other plant parts, which is from on the soil surface or buried inside the soil surface. The main aim of drip irrigation is to place water directly into the main root zone and decrease the water vapor. The system Drip irrigation spreads water through a schematic shape of different tubes, emitters, pipes, and valves. Its depending on the designed how well it make, maintained, installed, and operated it is, a system drip irrigation can be more useful than other various types of drip irrigation systems, like as sprinkler irrigation or surface irrigation. The system drip irrigation is firstly introduced mainly to save water and step-up the water use efficiency in agriculture field. More ever, it also presents various other social and economic benefits to the society. In drip irrigation system water is utalized micro jet or by drop by drop, on the surface of soil or under the soil, at a lower rate than the infiltration of the soil. In our this research, deeply research works heed water management for system drip irrigation and its upcoming advantages has been discussed and reviewed so that a precise perception may be existence for the farmers and for futures.
\end{abstract}

Keywords: Drip irrigation, dipper line, water, Fertigation system.

DOI: $10.7176 / \mathrm{JBAH} / 9-9-04$

Publication date:May $31^{\text {st }} 2019$

\section{Introduction}

Agriculture is actually responsible for seventy \% of aver all world's water use, growing for food and fiber crops, fodder for livestock, bio-fuel, and fiber for clothes which is used in our daily life (i.e. cotton). Kang and Nishigama (1996) introduced a simple method for designing laterals used in drip irrigation systems. In this method, given the average discharge required in emitters, the uniformity needed in water application. Among twenty $\%$ of the agricultural sector irrigates its crops, and yet that segment is responsible for fourty $\%$ of the food from planet's. Irrigation is main key, Barak argues, to improving or advancements of crop production. The system Drip irrigation passes the water to plants through a schematic system of emitters and pipes, and supply controlled and slow method of water. It is also high capital deeply than traditional irrigation systems, but apportions a very small quantity volume of water per unit of time with higher precision. It is established that the most ideal policy environment for promotion of micro irrigation technologies in the well-irrigated zones would be prorate pricing of electricity, which would create direct incentive for efficient water use (Kumar, 2005).

There are various forms of irrigation system. Now a day's very little farmer's atleast $4 \%$ who irrigate their soil by use of drip irrigation system. $12 \%$ of farmers are uses pivot irrigation system, another moderately efficient form of irrigation, whereas the other remaining eighty four \% still used flood irrigation system. See schematic structure of Drip Irrigation system shown in (Figure 3). Climatic problems associated with the surface method of irrigation system such as salinity and water logging are also completely absent under drip method of irrigation (Narayanamoorthy, 1997). The drip irrigation system helps in accomplishing saving in irrigation water, increased water-use efficiency, reduced tillage tools, higher quality products, increased crop yields and higher fertilizer-use efficiency (Qureshi et al., 2001; Sivanappan, 2002; Namara et al., 2005).

In modern era drip irrigation system was primarily introduced in California in the late 1960s. By a little over twenty years later it was adopted on only five $\%$ of irrigated land. Still fast-forward another 20 years and by 2010 over fourty \% of the irrigated land in California is irrigated which is used through drip irrigation systems (Tindula, Orang, and Snyder 2013). Having spread across many crops and zones in a non-linear trajectory, the system drip irrigation is a prime example of a process design whose diffusion, as we will presents, is defined by the theory laid out in the threshold and the real option value models. Pramanik and Patra (2016) described that high amount of water used and lower irrigation water use efficiency was determined under the conventional surface irrigation system. When indirectly supplied, irrigation technology 'can cause losses arising on investments create by farmers, Hence drop-off the economic water productivity index and the overall sustainability' (Battilani, 2012). Now we concentrate on drip irrigation system for 3 reasons: the $1^{\text {st }}$ one is, drip irrigation system was preference as one of the main success stories over the last one hundred years by an informal survey of California County Directors. And 2nd, it is timely to survey a technology whose adoption has 
been shaped by droughts during a period with a severe California drought. The $3 \mathrm{rd}$ one is, it is prime study of this sort for a technology that design to preserve a natural resource (water) such as rainfall water and the lessons of its dissemination may employ to similar technologies. In Addition, many growers still perceive groundwater pumping as somewhat in low costs than water supplied by the $\mathrm{CBC}$, even though the contrary was shown by economic analyses (e.g. Portoghese et al., 2013).

Sepaskhah and Hassanlee (2000) carried out a survey in 7 orchards which is presented in different parts of the city of Darab in the province of Fars as their sample with the purpose of evaluating drip irrigation systems. The system Drip irrigation is the exercise of employing small number of water and fertilizer high amount of agriculture land. The fertilizer and water are presents directly to the main root of the plant, terminate runoff, water vapor, and drift. A systematic designed way of drip irrigation system gives producers the good uniformity and application efficiency available, consequently saving them energy, time, and water, all while increasing yields and production. The average well-failure rate is fourty seven $\%$ for open-wells and nine $\%$ for bore wells (Palanismai et al., 2008).

The drip irrigation system is very ideal and important for to save or consumed water, due to population increases day by day in lack of water in future problems is created, so it is important to use such type of method to save the water and proper wateration. Flooding water is wasteful; it waste huge amounts of water, whileas increasing greenhouse gas emissions, expel methane, and dirty aquifers. Frequently it need children and women in poverty-stricken countries to waste more time truckage water in buckets by hand, devising it more hard for them to proceed education or to finalize other tasks. The system drip irrigation effects on all field crops but it is highly affected on banana, strawberry, tomatoes, and all kinds of vegetables, as shown in the (Figure 1).

Dokht-e-Bami (1997) described the economical aspect of employing pressurized irrigation systems, including drip irrigation system and bubble irrigation systems, for irrigating pistachio orchards in the province of Kerman, and concluded that drip irrigation system was economically more desirable. Mirlatifi and Daneshvar (2000) carried out a research experiment on the financial evaluation of drip irrigation system in the province of Khorasan and found that economic, social, and technical factors influenced the refusal to assume pressurized irrigation systems and that drip irrigation systems, if designed and utilized in a right manner, would be financially justifiable. Now this method is also introduced in many developed countries and it is also spreads in various countries where water is shortage, to consume the water drip irrigation is very important and ideal method. Therefore, it is necessary to develop more careful plans for using water resources, especially in the agriculture field that is the main usage of water in our country (Ghaheri, 1996).

Such causing exercises have been driven and recommended by EU policies. In previous years CAP subsidies Have tended to prefer crops with high water needs, like as maize, therefore increasing the risk of water losses under climatic uncertain conditions (Garcia- Vila and Fereres, 2012). Salemi and Ghassemi (2001) conducted a study to compare the different methods of pressurized irrigation system. 


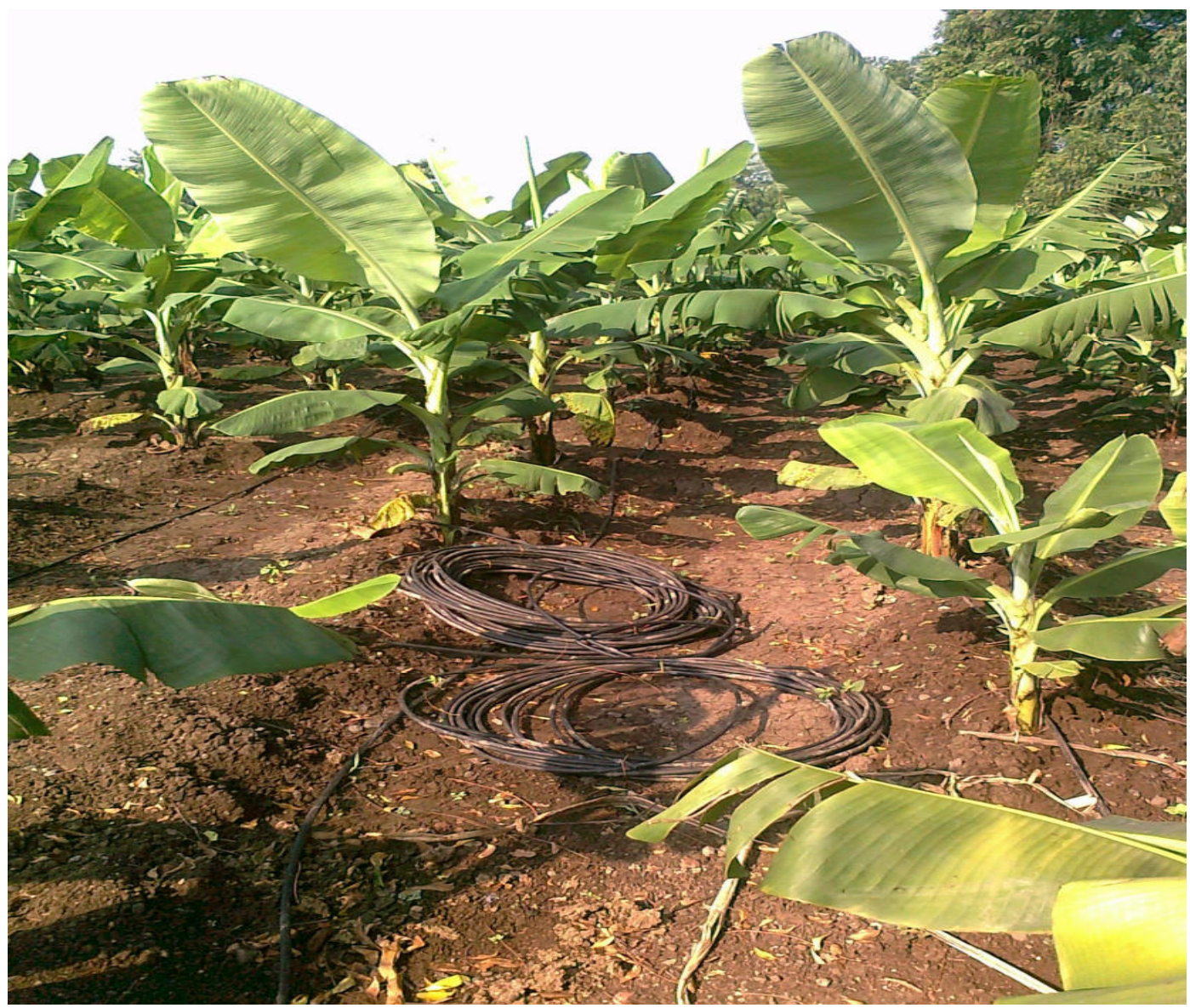

Figure 1. A type of Banana Drip pipe Irrigation system.

\section{Kinds of drip irrigation system}

The system drip irrigation products can be classified into 5 classes. These 5 options can be combined in any application, but keep in mind that every method may have various watering systems. So, it is usually recommended that the different methods be place on separate portions and controls apart, either multi-station or through sequence.

\section{The main source of drip irrigation:}

The major exact option, drip emitters irrigation system which present water directly to the root of the plant under the soil. Drip emitters irrigation system is best desirable to baskets, trees, shrubs, etc. due to of low discharge rate of water, the watering cycle is usually longer.

\section{Bubbler:}

This type of irrigation system is mostly frequently for trees and for shrubs, bubblers irrigation system have high amount of discharge rates and very slow watering period. Because bubblers irrigation system can manage at high pressures, they are specifically helpful for conversion from conventional sprinkler to low-volume systems.

\section{Micro-spray irrigation system:}

Micro-spray irrigation system is useful for when low amount of volume overhead irrigation is desired, microspray irrigation system is good for to covers ground, and plants like as ferns, which prefer some humidity.

\section{Dripper line irrigation system:}

The dripper line irrigation system is the speedily growing and easiest to install in drip irrigation system. For closely spaced plants watering, gardens, vegetable gardens, hedges, and so on. Dripper line irrigation system is the best choice. Other drip irrigation systems which include rings for large pots and planter boxes, as well as loops around large trees and containers.

\section{The Mister irrigation system:}

This type of irrigation system is ideal for creating humidity, and for watering hanging baskets, the misters' irrigation system is normally helpful for in the inverted position and spray downwards. A growing application of misters is used for outdoor cooling, whereas it immediate evaporation of water mister can dramatically decrease the air temperature. 
Enter drip irrigation,

This irrigation system have introduced by Netafim in 1965. This ideal irrigation system to give the plant watering it needs the plants, at the suitable time, and to irrigate the deep root of the plant, as opposed to the soil. This type of irrigation system is applied via plastic 'drip lines' that lay either on the soil or under the soil root. Water is managed at the source, whether it's a tank or reservoir water, and the soil around the plant receives a small, steady, and equal amount of water when the valve is opened.

There are two main types of drip irrigation systems - surface and sub-surface.

A surface system of drip irrigation is useful for close emitter spacing (10"-16") and a thin wall (9-12 mil) in which drip line injected 1" to 6" under the surface of soil. This type of irrigation systems are commonly recommended to as "temporary" because the drip line is recycle and retrieved yearly. The sub mains can be temporary or permanent. These types of systems are commonly used on high value crops, because it's too expensive and time consuming and also labour cost on yearly re installation.

One obstacle is not sufficient information about appropriate irrigation levels and scheduling over a growing season. Farmers generally lack enough assistance to create and adopt better approaches for Environmental sustainability, while also maintaining their financial and social objectives (Pereira et al., 2012). And a subsurface drip irrigation system (SDI) is used between 22" - 28" emitter spacing and is used for slightly thicker wall (12$16 \mathrm{ml}$ ) and injected in drip line 8" - 16" under the soil surface. These types of systems are regular, devising design and installation and are critical to ensure longevity. Sub surface irrigation systems is offently used in crop which is cultivated in row but are making their way into some high value field crops. Eco-Drip has been committed to subsurface drip irrigation system since installing our first system in 1980 .

Thus more dependable information systems and expert capacity are necessary to guide farmers in using water more efficiently (Battilani, 2013). The primitive drip irrigation system has been used since from past future ancient times. Fan Sheng-Chih Shu, written in China during the first century BCE, which demonstrates the use of buried, unglazed clay pots which is filled with water, sometimes referred to as Ollas, as a means of irrigation system. In new era drip irrigation system began its growth in Germany in 1860 when scientists began their research experimenting with subsurface irrigation system using clay soil pipe to design combination irrigation and drainage systems. The research was later increased in the 1920s to include the applying of perforated pipe irrigation systems. The usage of plastic to clasp and spreads water in drip irrigation system was later growth in Australia by Hannis Thill finally, farmers should share their personal experiences and knowledge in order to help others to use irrigation water in a sustainable and efficient way (reported in Ecowater, 2013).

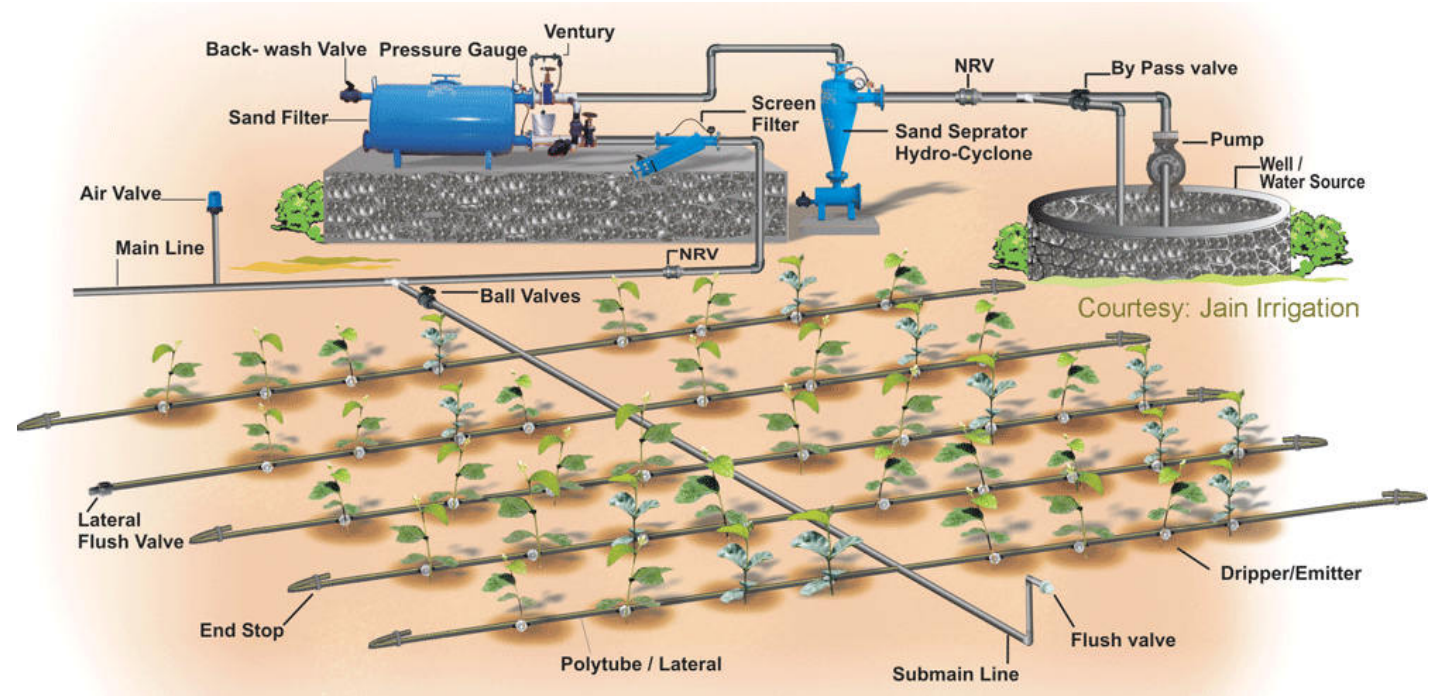

Figure 3. A schematic model structure of Drip Irrigation.

With used of high amounts of a plastic emitter in drip irrigation system was developed in Israel scientists by Simcha Blass and his son Yeshayahu. Instead of relinquish water through tiny holes which is easily blocked by small particles, water was relinquish through high and longer systematic ways by using velocity to slow water inside a plastic emitter. The first research experimental system of this type was established by Blass in 1959 who partnered later in (1964) with Kibbutz Hatzerim to design an irrigation company named as Netafim. After that they together designed and patented the first experiment surface drip irrigation emitter system. 
Moayyedinia (1998), in his research he conducted on the blockage of emitters in drip irrigation systems, came to the conclusion that the most important factor endangering the efficiency of these systems is the unsuitable quality of irrigation water which causes chemical, physical, and biological blockage. In the United States of America, the first drip tape, named as Dew Hose, was managed by Richard Chapin of Chapin Watermatics in the early 1960s century. Chapin Watermatics was acquired by Jain Irrigation in 2006 and is housed under its US subsidiary Jain Irrigation Inc, USA.

Indeed, land degradation and nutrient depletion significantly constrain chance to increase water efficiency (Molden et al., 2010; IST, 2013).

After that its prime foundation in California in the late 1960s centuries, only five percent of irrigated land is employ in this system by 1988 . By 2010 , fourty percent of irrigated land in California applied in this irrigation system.

'Using financial criteria for water efficiency rather than an engineering one appears a sensible approach when assessing irrigation performance at the farm level, since any managerial (e.g. scheduling) and Operational (e.g. equipment) inefficiencies associated with irrigation are implicitly included in the assessment' (Knox et al., 2012:3). In modern drip irrigation system has arguably become the worldest most important innovation in the field of agriculture since the conception in the 1930s of the impact sprinkler, which proffered the first experiment alternative to surface irrigation system. Drip irrigation system in small pots is also an ideal for Dianthus caryophyllus flowers, see (Figure 2). Drip irrigation system may also useful devices called micro-spray heads, which spray water in a small area, instead of dripping emitters system. In particular, advisory-extension services have enhanced irrigation practices which better fulfill potential benefits of irrigation technology (Genius et al., 2014; Gold et al., 2013). These are commonly used on vine and tree crops having large tap root zones. Subsurface drip irrigation is mostly useful for temporary or permanently buried dripper line or drip tape located at or under the plant roots. It is becoming most famous for row crop irrigation system, especially in these areas where water supplies are limited, or recycled water is used for irrigation. Although the main water supply is surface water, during recurrent water shortages farmers pump groundwater from medium-depth $(100-150 \mathrm{~m})$ aquifers, especially since the late 1990s (Portoghese et al., 2013). Deeply study of all the relevant factors such as water, soil, land topography, crop and agro-climatic conditions are needed to ascertain the most desirable drip irrigation system and components to be used in a specific installation.

Howell (2003) and Irmak et al. (2011) demonstrated the attainable application efficiencies for different irrigation methods, assuming irrigations are applied to meet the crops' water demands. Micro irrigation Has the potential to accomplish the highest uniformity (90\%) in water applied to each plant, yet poor Uniformity and application efficiency can result from various causes, e.g., inadequate maintenance, Low inlet pressure or pressure fluctuations, emitter clogging and inadequate system design ( Hsiao et al., 2007).

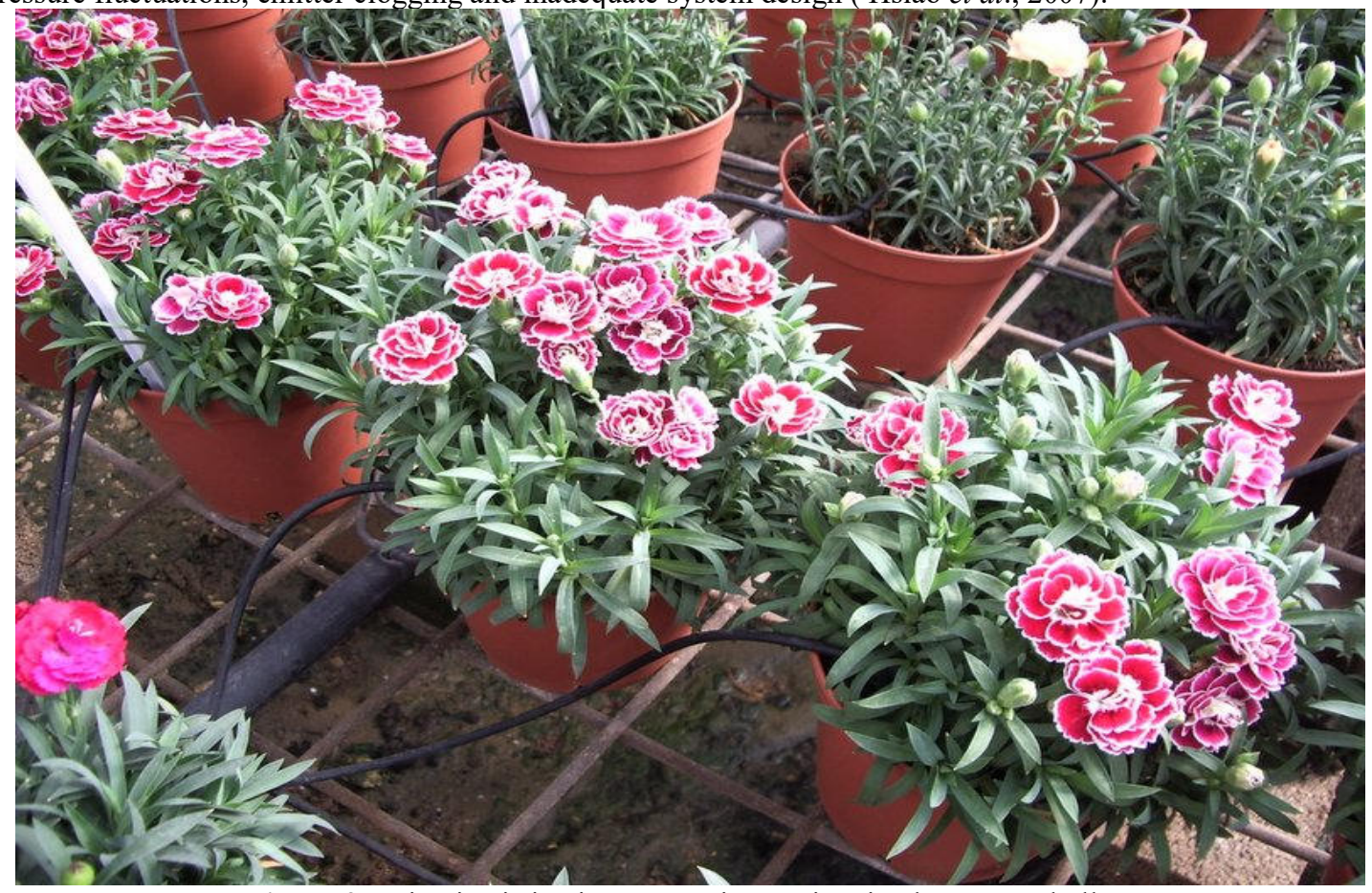

Figure 2. Drip pipe irrigation system in pots in Dianthus caryophyllus. 


\section{Factors used in drip irrigation system (listed in order from water source) which includes:}

- Water filter(s) or filtration systems: sand separator, Fertigation systems (Venturi injector) and chemigation equipment (optional)

- $\quad$ Pump or pressure water sources

- Backwash controller (Backflow prevention device)

- Smaller diameter polyethylene tube

- $\quad$ Pressure Control Valve (pressure regulator)

- Distribution lines (main larger diameter pipe, maybe secondary smaller, pipe fittings)

- Hand-operated, electronic, or hydraulic control valves and safety valves

- $\quad$ Poly fittings and accessories (to make connections)

- $\quad$ Emitting devices at plants (emitter or dripper, micro spray head, inline dripper or inline drip tube)

In the drip irrigation systems, valves and pumps may be automatically or manually managed by a restrainer. The main large drip irrigation system applies some type of filter to forestall clogging of the small emitter flow path by small waterborne exercises. Modern technologies are now being proffers that minimize congest. Yet such models cannot reconcile stakeholders' different understandings of irrigation efficiency: farmers seek to maximize their economic benefits, while, water experts or seek to conserve Water (Knox et al., 2012). Whereas the some residential systems are installed without additional filters since drinking water is already filtered at the water plant. Virtually all drip irrigation tools manufacturers recommend that filters be employed and generally will not honor warranty unless it's finished. Last line filters just before the last delivery pipe are strongly recommended in improver to any other filtration system due to fine particle settlement and inadvertent insertion of particles in the center lines. Drip and subsurface drip irrigation system is commonly used solely when using recycled municipal wastewater. Regulations typically do not permit spraying water through the air that has not been fully treated to drinking water standards.

Farmers experience ascension water costs as an extra penalty. Rather than higher water costs, administrative water allocation or re-allocation lowering the supply often has led farmers to adopt water-efficiency practices (Molden et al., 2010). Because of the method the water is employed in a drip irrigation system, traditional surface applications of timed-release fertilizer are sometimes not effective, so drip irrigation systems usually mixed liquid fertilizer with the irrigation water. This method is called as fertigation; fertigation and chemigation (application of chemicals and other pesticides to sporadically clean out the system, like as sulfuric or chlorine ) due to use of chemical injectors like as piston pumps, diaphragm pumps, or aspirators. The chemicals may be added invariably whenever the system is irrigating or at intervals. If agricultural water demand is inelastic, then policies which encourage changes in cropping patterns can be more effective than higher prices (Fraiture and Perry, 2007; Iglesias and Blanco, 2008; Kampas, 2012). Fertilizer consuming of up to ninety five percent are being described from recent university field tests using drip fertigation and slow water delivery as compared to timed-release and irrigation by micro spray heads.

Drip irrigation system designed properly, managed, and installed, may help to consume water by decreasing water evaporation and deep drainage when it compared to the other alternatives of irrigation such as overhead or flood sprinklers since water can be more precisely employ to the plant main roots. Moreover, drip irrigation system can terminate various diseases that are distributes through water contact with the foliage. Besides simplifying the network operations, this technology proved to be very useful for accurate monitoring and control of water distribution, and for achieving better understanding of the irrigation management practices followed by farmers, especially through the possibility to retrieve and analyse historical data series (Zaccaria et al., 2013). Ultimately, in zones where water supplies are very limited, in that way there is no system for consumed water, but rather simply an increase in production while using the same amount of water as before. In very arid regions or on sandy soils, the recommended way is to supplies the irrigation water as slowly as possible. Yet even WP remains distant from farmers' perspectives. They generally perceive 'irrigation efficiency' as maximizing net revenue rather than saving water (Knox et al., 2012).

The Pulsed irrigation system is commonly used to diminish the amount of water presents to the plant at any time, therefore decreasing runoff or deep infiltration. Pulsed irrigation systems are typically so costly and it needs extensive maintenance, labour cost and time consuming. Thus, the new efforts by emitter producers are concentrates on generating new technologies that supplies irrigation water at very small flow rates, such as less than 1.0 liter per one hour, tiny and even delivery further ameliorates water utalized efficiency without incurring the costly and complexity of pulsed delivery tools. An emitting drip pipe irrigation system is a kind of drip irrigation system tubing with emitter's pre-managment at the factory with specific distance and flow per hour as per crop distance. Towards that economic aim, most growers make irrigation decisions by relying on subjective judgments, based only on their practical experience and observation (Knox et al., 2012).

An emitter bounds water flow transit through it, therefore producing head loss needs (to the extent of atmospheric pressure) in other way to emitter water in the form of drop by drop. This head loss is accomplished 
by turbulence/friction among the emitter.

Table 2. The total area moisture by one emitter depending on type of soil (Source: Rainbird International, 1980).

\begin{tabular}{|l|l|}
\hline Soil Type & Area moisture by one Emitter $(\mathbf{m} 2)$ \\
\hline Sandy Soil & $0.5-2$ \\
\hline Loamy Soil & $2-6$ \\
\hline Clay & $6-15$ \\
\hline
\end{tabular}

Total number of emitters per plant and emitter spacing

The number of the emitters needs per plant is described as under

Emitted per plant $=\underline{\text { Area per plant } \mathrm{x} \mathrm{PW}}$

Aw

Area per plant (m2)

$\mathrm{Pw}=$ Percentage wetted area/100 $(\% / 100)$

$\mathrm{Aw}=$ Area wetted by one emitter $(\mathrm{m} 2)$

\section{Advantages and disadvantages}

The advantages of drip irrigation are:

The method drip irrigation system is a ideal for a number of applications, which including watering landscapes, larger trees, foundation planting and raised planters, shrubs, roadways and medians, and subsurface sports fields and turfs. And has many other benefits which include as:

Water consuming: The drip irrigation can decrease water use by thirty to seventy $\%$ compared to conventional sprinkler irrigation. The system sprinklers can waste more water due to scattered spray from evaporation, winds, deep leaching or run-off.

Salubrious plants: Mainly the shrubs, plants and turf grass thrive with a slow and steady applies of nutrients and water directly to the main plant's roots. The ideal soil wetted level also decrease plant stress, which prodding plants growth very fast. The drip irrigation system also precludes unsightly brown spots on flowers due spray never touches the plants parts, and it decreases other diseases such as fungal by keeping the soil surface and foliage dry.

Aesthetics: There are no unnoticeable risers or sprinkler heads to lessen the aesthetic value of a landscape. Drip irrigation system can be hidden under beneath or mulch the soil, which also terminates spray on windows, buildings, pedestrians or fencing in high-traffic areas.

Decrease growth of weed: Because the drip irrigation system only covers a relatively very small portion of the surface of the soil's near the plant, weeds pertains short water and later have less chance to develop.

Mechanisation: The drip irrigation systems can easily be automated by through hooking the system into conventional electric valves and timers.

Optimal fertilization. Water-soluble food plant can easily be utilized through the filter, using drip system, to the plant main root directly.

Slopes and its uses. Traditional sprinklers commonly create wasteful run-off when used to water upper slopes of hills. The drip irrigation system utalized the water gradually enough to let off all the wetted to soak directly into the soil.

Decreased labor and other maintenance. The dripline installations have low average material expensence when it compared to conventional sprinklers. And, sprinklers needs equal maintenance to adjust nozzles and spray patterns, and have moving parts that needs repair. Dripline maintenance is very short and limited to periodic flushing and system evaluation.

Easy installation. Dripline irrigation system managed easily in tight, awkwardly shaped areas that are difficult to water with standard sprinkler systems. Dripline system is typically very pliable and can accommodate to any planting shape.

- Nutrients and Fertilizer loss is decreased due to a localized application and reduced leaching.

- Water application efficiency is high if managed correctly.

- $\quad$ Leveling of Field is not important.

- Irregular shapes Fields are easily accommodated.

- $\quad$ Recycled non-potable water can be safely used.

- $\quad$ Moisture within the root zone can be maintained at field capacity.

- $\quad$ Soil type plays a less important role in the frequency of irrigation.

- $\quad$ Soil erosion is deceased.

- Weed growth is deceased.

- Water distribution is highly constant, controlled by the output of each nozzle.

- As compare to other methods of irrigation system Labour cost is less. 
- Variation in supply can be regulated by regulating the drippers and valves.

- $\quad$ Fertigation can easily be included with minimal waste of fertilizers.

- $\quad$ Foliage remains dry, decreasing the risk of disease.

- Commonly operated at lower pressure than other types of pressurized irrigation, reducing energy costs.

The drip irrigation disadvantages are as:

- $\quad$ Prime cost can be more than overhead systems.

- The sun light can affect the tubes used for drip irrigation system, shortening their lifespan. (See Polymer degradation);

- The risks of degrading plastic affecting the soil content and food crops. With many types of plastic, when the sun degrades the plastic, causing it to become brittle, the estrogenic chemicals (that is, chemicals replicating female hormones) which would cause the plastic to retain flexibility have been released into the surrounding environment.

- If the water is properly not filtered and the equipment properly not maintained, it can result in bioclogging or clogging.

- For subsurface drip irrigation system the irrigator cannot see the water that is utalized. This may lead to the farmer either employing so much water (low efficiency) or an low amount of water; this is specifically common for those with less experience with drip irrigation.

- Drip irrigation system might be unsatisfactory if herbicides or top dressed fertilizers need sprinkler irrigation for activation.

- Drip tape needs extra cleanup expance after harvest. Users require planning for drip tape disposal, winding, reuse or recycling.

- Water wastage, time and harvest, if properly not installed. These systems need deep study of all the relevant factors such as water, soil, land topography, crop and agro-climatic conditions, and desirably of drip irrigation system and its components.

- In lighter soils subsurface drip irrigation system may be enabling to moisture the soil surface for germination. Needs deeply consideration of the installation careful.

- Usually the drip irrigation systems are manufactured for high efficiency, meaning little or no leaching fraction. Without sufficient leaching, salts applied with the irrigation water may build up in the root zone, commonly at the edge of the moisture pattern. Whereas, the drip irrigation systems obviate the high capillary potential of traditional surface-applied irrigation, which can draw salt deposits upwards from deposits downwards.

- The PVC type pipes usually suffer from damaged by rodent, needs replacement of the inside the tube and increasing costs.

- The drip irrigation systems cannot be used for damage control by night frosts (like in the case of sprinkler irrigation systems).

\section{Drip tape}

Drip tape is a kind of thin-walled dripper line which is commonly used in drip irrigation. The first drip tape was known as "Dew Hose". Drip tape duct tape is made of polyethylene and is sold flat on reels. The wall thickness typically ranges from 4 to 24 miles $(0.1-0.6 \mathrm{~mm})$. Thicker walled tapes are usually used for regular subsurface drip irrigation system and thinner walled tapes for temporary throw-away type systems in high-value crops.

Water exits the tape through drippers or emitters. The typical emitter spacing ranges from 6 to 26 inches $(150-600 \mathrm{~mm})$. In some products, the emitters are produced simultaneously with the tape and are actually formed as part of the product itself. In others, the emitters are manufactured separately and installed at the time of production. Due to the resemblance of the branches to the tail of pigs, this layout of emitters is also referred to as pigtail layout (Alizadeh, 2004).

Some product is not a tape, but a thin-walled dripper line, but in popular parlance, both types of products are called tapes. Typical tape diameters are 5/8", 7/8", and 1-3/8", with the larger diameters more usually used on permanent installations with longer runs. Drip tape is a recyclable material and can be recycled into viable plastic resins for reuse in the plastics manufacturing industry.

\section{Uses of Drip irrigation system}

The drip irrigation system is used in commercial, farms, greenhouses, and residential gardeners. Drip irrigation system is adopted widespread in areas of acute water scarcity and especially for crops and trees such as coconuts, landscape, grapes, ber, banana, citrus, eggplant, sugarcane, strawberry, cotton, tomatoes and maize. In general way, analysis of any irrigation system that is based on measurements in actual field conditions, and while the system is working normally, is called evaluation of the system (Merrian and Keller, 1978); and since the 
performance of the system varies in time, it must be constantly evaluated (Roth et al.,1995). Drip irrigation system for garden available in drip kits are progressively famous for the homeowner and consist of a timer, hose and emitter. Hoses that are $4 \mathrm{~mm}$ in diameter are used to irrigate flower pots. As described by (Lee. 1998) that crop yield increased with increases in the uniformity of water application, and that water distribution in drip irrigation was better than in surface irrigation. Halil et al., (2004) obtained from their study of nine drip irrigation systems (including seven ordinary systems and two automatically variable systems) showed that only one of the ordinary systems and both automatically variable systems enjoyed desirable efficiencies.

\section{Conclusion}

The study clearly suggests the advantage of drip and fertigation with applying precise amounts of water and fertilizer nutrients over surface irrigation and conventional soil fertilization for crop production. It is concluded from the study that drip irrigation system favorably determined the yield which resulted in higher irrigation WUE against lower amounts of water application. Apart from advantage of water saving over conventional irrigation, drip irrigation system demonstrates to be very effective and useful method of irrigation for growing of crop. In addition, a benefit-cost ratio with different discount rates points out that investment in drip irrigation cultivation is economically important. The pattern of drip irrigation system should be inspired in the all fields. Since the farmers are getting water for the low cost from the public irrigation system, they are least interested to assume this technology. Considering the rapid decline in irrigation-water availability and low water-use efficiency under the conventional method, appropriate initiatives should be taken to spread the area under drip fertigation to obviate demand-supply gap in water-use in the near future. The private benefit-cost ratio, estimated using discounted cash flow methods, has distinctly points that drip investment is economically viable even without subsidy.

Funding; This research project was financially supported by the Henan Province key R \& D and extension Project (182102110048) and Key Scientific Research projects in Henan Colleges and Universities (17B180001).

Acknowledgement: I am really very thankful to my entire lab colleague they help me during this research project. I also heartly thank full to Prof. Dr. Fan Shuli and teacher ma Qifeng they guide me and support me to write this review paper.

Conflict of interests: The authors declare that there is no conflict of interests.

\section{References}

1. Bainbridge, David A (June 2001). Buried clay pot irrigation: a little known but very efficient traditional method of irrigation". Agricultural Water Management. 48 (2):79-88. Doi: 10.1016/S0378-3774(00)001190 . Retrieved 23 October2013.

2. Burt, C.M. and S. W. Styles. 2007. Drip and Micro Irrigation Design and Management for Trees, Vines, and Field Crops. 3rd Edition. Irrigation Training and Research Center, 2007;

3. Drip irrigation tape and method of manufacture Patents.com". www.patents.com. Retrieved 2017-09-30.

4. "Jain Irrigation". www.JainsUSA.com. Retrieved 19 December 2017.

5. New AG International Jain Irrigation Announces Acquisition of Chapin Watermatics Inc". www.newaginternational.com. Retrieved 2017-09-30.

6. DEW-HOSE Trademark - Registration Number 0847046 - Serial Number 72249303: Justia Trademarks". Trademarks. Justia.com. Retrieved 2016-06-12.

7. Dixit and Pindyck 1994. Developed and popularized option value models in regards to investment under uncertainty. These models recognize the option value of waiting for better information before making the decision to invest.

8. Pramanik S, Patra SK. 2016. Growth, yield, quality and irrigation water use efficiency of banana under drip irrigation and fertigation in the gangetic plain of west Bengal. World Journal of Agricultural Sciences 12(3):220-228.

9. Pramanik S, Tripathi SK, Ray R, Banerjee H. 2014. Economic Evaluation of Drip-fertigation System in Banana cv. Martaman (AAB, Silk) Cultivation in New Alluvium Zone of West Bengal.Agricultural Economics Research Review, 27:103-109.

10. R. Goyal, Megh 2012. Management of drip/trickle or micro irrigation. Oakville, CA: Apple Academic Press. p. 104. ISBN 978-1926895123.

11. Taylor, Zilberman, Rebecca, David 2015. "The Diffusion of Process Innovation: The Case of Drip Irrigation in California".

12. Yang, Chun Z.; Yaniger, Stuart I.; Jordan, V. Craig; Klein, Daniel J.; Bittner, George D. (1 July 2011). "Most Plastic Products Release Estrogenic Chemicals: A Potential Health Problem That Can Be Solved". Environmental Health Perspectives. 119 (7): 989-996. Doi: 10.1289/ehp.1003220. PMC 3222987. PMID 21367689.

13. Ghaheri A, Ghravi H, Zolfaghari A, Borhan N. 1996. Evaluation of the Performance of Irrigation Systems 
and Identification of Factors Affecting It, the National Committee on Irrigation and Drainage of Iran, pp. $146-148$.

14. Battilani, A., 2012. Sustainable Knowledge-based Irrigation Management: The IRRINET package, http://ec.europa.eu/environment/archives/greenweek2012/ Adriano battilani. Html http://ec.europa.eu/environment/archives/greenweek 2012/sites/default/files/3-9 battilani.pdf .

15. Battilani, A., 2013. Approaches to Improve the Productivity of Water, Use in Irrigation with diagrams, http://www.wsstp.eu/files/WSSTPX0001/II 2\% 20 Adriano \% m 20 Battilani.pdf.

16. Garcia-Vila, M., Fereres, E., 2012. Combining the simulation crop model Aqua Crop with an economic, model for the optimization of irrigation management at farm level. Eur. J. Agron. 36,21-31

17. Molden, D., Oweis, T., Steduto, P., Bindraban, P., Hanjra, M.A., Kijne, J., 2010. Improv- ing agricultural water productivity: between optimism and caution. Agric. Water Manage. 97, 528-535.

18. Kampas, A., Petsakos, A., Rozakis, S., 2012. Price-induced irrigation water saving: unraveling conflicts and synergies between European agricultural and water policies for a Greek water district. Agric. Syst. 113 (1), 28-38.

19. Knox, J.W., Kay, M.G., Weatherhead, E.K., 2012. Water regulation, crop production and agricultural water management understanding farmer perspectives on irrigation efficiency. Agric. Water Manage. 108 (1), 3-8.

20. Howell, T.A., 2003. Irrigation efficiency. In: Encyclopedia of Water Science., http://dx.doi.org/10.1081/EEWS120010252,http://www.researchgate.net/publication/43 256707 Irrigation Efficiency.

21. Irmak, S., Odhiambo, L.O., Kranz, W.L., Eisenhauer, D.E. 2011. Irrigation Efficiency and Uniformity, and Crop Water Use Efficiency, Lincoln, NB: University of Nebraska-Lincoln Extension, http://extension.unl.edu/publications.

22. Hsiao, T.C., Steduto, P., Fereres, E., 2007. A systematic and quantitative approach to improve water use efficiency in agriculture. Irrig. Sci. 25,209-231.

23. Pereira, L.S., Cordery, I., Iacovides, I., 2012. Improved indicators of water use performance and productivity for sustainable water conservation and saving. Agric. Water Manage. 108, 39-51.

24. Genius, M., Koundouri, P., Nauges, C., Tzouvelekas, V., 2014. Information transmission in irrigation technology adoption and diffusion: social learning, extension services, and spatial effects. Am. J. Agric. Econ. 96 (1), 328-334.

25. Gold, A.J., Parker, D., Waskom, R.M., Dobrowolski, J., O’Neill, M., Groffman, P.M., Addy, K., 2013. Advancing water resource management in agricultural, rural, and urbanizing watersheds: why land-grant universities matter. J. Soil Water Conserv. 68 (4), 337-348.

26. Portoghese, I., D’Agostino, D., Giordano, R., Scardigno, A., Apollonio, C., Vurro, M., 2013. An integrated modeling tool to evaluate the acceptability of irrigation constraint measures for groundwater protection. Environ. Modell. Softw. 16, 90-103.

27. Zaccaria, D., Lamaddalena, N., Neale, C.M.U., Merkley, G., 2013. Simulation of peak-demand hydrographs in pressurized irrigation delivery systems using a deterministic-stochastic combined model. Part II: Model applications. Irrig. Sci. 31, 193208.

28. Ecowater, 2013. Deliverable 6.1: Synthesis report from the $1^{\text {st }}$ Round of Case Study Events. Ecowater, http://environ.chemeng.ntua.gr/ecoWater/Default.aspx? $\mathrm{t}=238$.

29. IST, 2013. Avaliac, ambient strategies dos novas investment EFMA relatives' à Reed Secondary de Rega, no ambit do INALENTEJO (Strategic Environmental Assessment of new EFMA's Investments). In: Relatório preliminary: Relatório Ambiental. Institute Superior Technical (IST), Lisbon, available online at http://www.inalentejo. Qren.pt/images /stories/file980.pdf.

30. Moayyedinia AH. 1998. The Effects of Chemical Compounds in Irrigation Water on the Blockage of Emitters in Drip Irrigation, M.Sc. thesis, the Industrial University of Isfahan.

31. Sepaskhah AR, Hassanlee AM. 2000. Evaluation of Drip Irrigation Systems, a Case Study on Citrus Orchards of the city of Darab, the Journal of Agriculture and Natural Resources, 4(2):13 - 27.

32. Salemi HR, Ghassemi AA. 2001. Evaluation of Changing from Surface Irrigation to Drip Irrigation in Old Apple Orchards in the City of Semirom, the Journal of Agricultural Engineering Research, 2(8): 25 - 40.

33. Kang Y, nishigama S. 1996. A simplified method for design of micro irrigation laterals. ASAE, 39:16811687.

34. Halil K, Dogan E. 2004. Determination of hydraulic performance of trickle irrigation Emitters used in irrigating systems in the Harran plain. 9- 13.

35. Merrian JL, Keller J. 1978. Farm Irrigation system Evaluation: A guide for management. Utah state univ, Utah.

36. Roth R, Sanchez C, Gardner B. 1995. Growth and yield of mature Valencia oranges converted to pressurized irrigation system. Applied Engineering in Agriculture, pp.101-105.

37. Alizadeh A. 2001. Principles and Practices of Drip Irrigation, the University of Emam Reza (PBUH), Mashhad, pp.157 - 168 and 384 - 385. Alizadeh A. 2004. Designing Irrigation Systems, the University of 
Emam Reza (PBUH), Mashhad, pp. 439 - 441.

38. Dokht-e-bami M. 1997. Economic Evaluation of Pressurized Drip and Bubble Irrigation systems, M.Sc. Thesis, Oroumiyeh University, Iran.

39. Mirlatifi M, Daneshvar M. 2000. Financial Evaluation of Drip Irrigation Projects in the Province of Khorasan, the Journal of Agricultural Economics and Development. 8(32): 117 - 134

40. Narayanamoorthy, A. 1997. Drip irrigation: A viable option for future irrigation development, Productivity, 38 (3): 504-511.

41. Narayanamoorthy, A. 2003. Averting water crisis by drip method of irrigation: A study of two water intensive crops, Indian Journal of Agricultural Economics, 58(3): 427-437.

42. Narayanamoorthy, A. 2005. Economics of drip irrigation in sugarcane cultivation: Case study of a farmer from Tamil Nadu, Indian Journal of Agricultural Economics, 60 (2): 235-248.

43. Qureshi, M.E,, Wegener, M.K., Harrison, S.R. and Bristow, K.L. 2001. Economic evaluation of alternate irrigation systems for sugarcane in the Burdekin delta in North Queensland, Australia, In: Water Resource Management, Eds: C.A. Brebbia, K. Anagnostopoulos, K. Katsifarakis and A.H.D. Cheng, WIT Press, Boston, pp. 47-57.

44. Sivanappan, R.K. 1994. Prospects of micro-irrigation in India, Irrigation and Drainage Systems, 8 (1):49-58.

45. Sivanappan, R.K. 2002. Strengths and weaknesses of growth of drip irrigation in India, In: Proc. of Micro Irrigation for Sustainable Agriculture. GOI Short-term training 19-21 June, WTC, Tamil Nadu Agricultural University, Coimbatore.

46. Kumar, M. Dinesh 2005. Impact of electricity prices and volumetric water allocation on groundwater demand management: Analysis from western India, Energy Policy, 33 (1).

47. Kumar, M. Dinesh, Turral, Hugh, Sharma, Bharat, Amarasinghe, Upali and Singh, O. P. 2008. Water Saving and Yield Enhancing Micro-Irrigation Technologies in South Asia: When and Where Can they become Best Bet Technologies? International Water Management Institute, Patancheru, Hyderabad.

48. Palanisami, K., Vidyavathi, A. and Ranganathan, C.R. 2008. Wells for welfare or ill fare: Cost of groundwater depletion in Coimbatore, Tamil Nadu, India, Water Policy, 10(4): 391-407. 